\title{
БІБЛЕЇЗМИ В УКРАЇНСЬКІЙ ТА АНГЛІЙСЬКІЙ МОВАХ: ТЕРМІНОЛОГІЧНИЙ І ФУНКЦІОНАЛЬНО-СЕМАНТИЧНИЙ ВИМІРИ
}

\begin{abstract}
Стаття присвячена з'ясуванню підходів до розуміння сутності та диференційних рис явища прецедентності в сучасній лінгвістиці й опису основних ознак прецедентного тексту як иіннісно-когнітивної універсалї певного соиіуму. Явище прецедентності досліджують у межах різних лінгвістичних напрямів, щзо підтверджує, з одного боку, його поширеність, з іншого - роль у комунікативній практиці. 3'ясований історико-культурний аспект явища прецедентності, його виміри, а також особливості реалізації на референційному, когнітивному та вербальному рівнях. Розглянуте співвідношення понять «прецедентний текст» $i$ «прецедентний феномен», визначена їхня корелячія з біблійним текстом, зокрема обтрунтоване потрактування Біблї, яка є знаком християнської культури, як прецедентного феномену. Прецедентні феномени можуть мати як національноспецифічний чи історично зумовлений, так і універсальний статус. Біблія є яскравим тому прикладом. Святе Письмо - прецедентний текст насамперед християнського релігійного дискурсу. У межах інших дискурсів вона може бути або визнаною авторитетним джерелом, або допускатися, або ж не визнаватися взагалі. Поняття прецедентності та прецеедентного тексту є історично плинним $і$ залежить від багатьох чинників. «Знання прецеедентних феноменів говорить про належність реципієнта до певної епохи, ї̈ культури, незнання ж їх свідчить про відторгнення від иієєї культури, щчо говорить про його відстороненість від иүієї культури або неповну "зануреність” у у неї». Дослідження прецедентності у діахронії засвідчує, щзо спектр прецедентних феноменів у кожного покоління буде відмінним від попереднього. Знання їх є показником певної епохи та культури. Біблія входить у інші тексти на різних рівнях: циитації, імен, натяків і лексико-фразеологічних вкраплень або біблеїзмів, які становлять потужний прошарок у мовах християнських народів. Перспективним напрямом подальших досліджень автор визначає з 'ясування характерних рис вживання біблеїзмів у різних функиіонально-семантичних типах дискурсу, зокрема публіцистичному.
\end{abstract}

Ключові слова: Біблія, прецุедентність, прецеедентний текст, прецеедентний феномен.

\author{
Ruslan VAKARIUK, \\ orcid.org/0000-0002-7107-7983 \\ Assistant at the Department of Foreign Languages for Natural Sciences \\ of the Faculty of Foreign Languages \\ Yuriy Fedkovych Chernivtsi National University \\ (Chernivtsi,Ukraine)umiks@ukr.net
}

\section{BIBLEISMS IN UKRAINIAN AND ENGLISH LANGUAGES: TERMINOLOGICAL AND FUNCTIONAL SEMANTIC DIMENSIONS}

The article deals with identifying approaches to understanding the essence and differential features of the phenomenon of precedence in modern linguistics, and describing the main features of the precedent text as a value-cognitive universal of a particular society. The phenomenon of precedence is studied within different linguistic directions, which confirms, on the one hand, the prevalence of this phenomenon, and its important role in communicative practice on the other. The historical and cultural aspect of the phenomenon of precedent, its dimensions, as well as the peculiarities of implementation at the reference, cognitive and verbal levels are clarified. The relationship between the concepts of "precedent text" and "precedent phenomenon" is considered, and their correlation with the biblical text is determined, in particular, a reasonable interpretation of the Bible, which is a sign of Christian culture as a precedent phenomenon, is substantiated. Precedent phenomena can have both national-specific or historically determined status, and universal one. The Bible is a clear example of this. The Holy Scripture is a precedent text primarily for Christian religious discourse. Within other discourses, it can be either a recognized authoritative source, or allowed, or not recognized at all. The notion of precedence and precedent text is historically unstable and depends on many factors. "Knowledge of precedent phenomena indicates that the recipient belongs to a certain era, its culture, and ignorance indicates a rejection of this culture, his alienation from this culture or incomplete 'immersion' in it." The study of precedent in diachrony shows that the spectrum of precedent phenomena in each generation will be different from the previous one. Their knowledge is an 
indicator of a certain era and culture. The Bible is included in other texts at various levels: quotations, names, allusions, lexical and phraseological inclusions or biblicalisms, which are a powerful layer in the languages of Christian peoples. The author identifies clarifying characteristic features of the use of biblicalisms in various functional semantic types of discourse, in particular, publicistic discourse, as a promising direction of further research.

Key words: Bible, precedence, precedent text, precedent phenomenon.

Постановка проблеми. Біблія - текст, який став знаковим для християнської культури, визначивши підвалини світобачення і світосприйняття значної частини людства. Вона й досі залишається потужним чинником впливу на людину, емотивним і когнітивним подразником, джерелом алюзій і ремінісценцій, що посилюють прагматичну насиченість дискурсу, у який вони уведені, а отже, справедливим є зарахування іiі до одного iз найпродуктивніших прецедентних феноменів у світовій культурі.

Аналіз досліджень. Явище прецедентності досліджують у межах різних лінгвістичних напрямів, що підтверджує, з одного боку, його поширеність, $з$ іншого - роль у комунікативній практиці. До понять прецедентного тексту і прецедентного феномену зверталися у своїх працях лінгвокогнітивісти (Д. Гудков, В. Красних, Г. Слишкін), лінгвокультурологи (В. Костомаров, Ю. Прохоров), представники структурно-семантичного напряму (А. Кожин, В. Мокієнко, О. Савченко, К. Сидоренко), а також комунікативно-прагматичного (О. Дмитрієва, Л. Дядечко, О. Земська, С. Сметаніна) та функціонального (Ю. Гунько, К. Іванова, С. Плотнікова, Ю. Сорокін, А. Супрун). Тому й підходів до ïx витлумачення, а також до з'ясування семантичних відношень, у яких вони перебувають, $є$ чимало, що робить актуальною потребу їх узагальнення.

Мета статті - розглянути поняття прецедентності, прецедентного тексту та прецедентного феномену на прикладі Біблії як одного 3 найпродуктивніших джерел змістово-ціннісних імплікатур християнської культури.

Виклад основного матеріалу. Із лінгвістичного погляду біблеїзми належать до лексико-фразеологічної підсистеми мови. У іiі межах вони формують окремий клас одиниць, що, з одного боку, мають низку особливостей (у функційносемантичному аспекті - це належність до релігійного дискурсу, у граматичному - можлива наявність архаїчних форм, у лексичному - застарілих лексичних компонентів чи стертих сьогодні лексико-семантичних варіантів), а 3 іншого - мають ті самі родові класифікаційні ознаки, що й решта одиниць фразеологічної підсистеми, адже належать до фразеологізмів.

Фразеологізм, або фразеологічна одиниця основна одиниця фразеології. Традиційно ним називають семантично неподільний комплекс, який містить два або більше повнозначні лексичні компоненти та якому властиві відтворюваність, цілісність значення, стійкість лексичного складу та граматичної будови. Серед їхніх важливих ознак - семантична цілісність, тобто значення фразеологічних одиниць не може бути витлумачене чи інтерпретоване на основі значень його складників: a round peg in a square hole - бути не на своєму місці, to draw the wool over someone's eyes - обманювати когось, to buy a pig in a poke - придбати щось, не знаючи його якостей, as like as two peas in a poke - дуже схожі.

Уперше термін «прецедентний текст» увів у лінгвістичний обіг російський мовознавець Ю. Караулов, котрий визначив його як текстове утворення, що поєднує у собі три визначальні ознаки (Караулов, 2007: 45):

1) є пізнавально і ціннісно значущим для певної особистості;

2) має надособистісну природу, тобто відомий не тільки самій особистості, а й іншим людям із іiі близького й віддаленого оточення, а також нащадкам і попередникам;

3) до нього особистість неодноразово звертається у своїй комунікативній практиці.

Оскільки, як свідчать наведені ознаки, текст набуває рис хрестоматійності для певної особи, вона вдається до нього за різних ситуацій і в різні періоди свого життя, що позначається і на його інтерпретації. У зв'язку із цим Ю. Караулов уводить поняття «реінтерпретованості» таких текстів (Караулов, 2007: 69). Ідеться про те, що постійне звернення до них мовців веде до переосмислення тих чи тих фрагментів, внаслідок чого відбувається вихід за межі того, що було від початку закладено в сам текст. Звідси й можливість окремих фрагментів «жити поза межами тексту», тобто залишатися впізнаваними й емоційно та когнітивно вартісними й поза межами певного вербального комплексу. У контексті Біблії ідеться про можливість функціонування узятої з нього вербальної одиниці, яка залишатиметься маркованою зв'язком із цим текстом (Селіванова, 2006: 216).

Поступово такі «реінтерпретовані» частини тексту перестають бути його фрагментами й перетворюються на «факти культури». Такими фактами культури стають, наприклад, біблійні тридцять срібників, за які Іуда зрадив Ісуса Христа, «заборонений плід із дерева пізнання» зі Старого Завіту чи змій-спокусник. 
Поступове переосмислення й уточнення дефініції, яку дав нововведеному поняттю «прецедентного тексту» Ю. Караулов, зумовило появу чималої кількості його потрактувань, наприклад:

- це закінчений, самодостатній продукт мовленнєво-мисленнєвої діяльності, (полі)предикативна одиниця і складний знак, відомий кожному представникові певної лінгвокультурної спільноти, звернення до якого у процесі комунікації відбувається знову і знову через пов'язані з цим текстом висловлювання і символи (Форманова, 2020);

- це потенційно автономний мовленнєвий змістовий блок, котрий актуалізує значущу для автора фонову інформацію й апелює до культурної пам'яті читача, що виникає як результат значеннєвої компресії вихідного тексту і форма його «метонімічної заміни» (Воробйова, 2003:107).

- це відомий твір, актуалізований в інших текстах, повернення до якого кероване механізмами інтертекстуальності (Меркотан, 2014: 179-183);

- це завершений і самодостатній продукт мовленнєво-мисленнєвої діяльності; поліпредикативна одиниця; складний знак, добуток значень компонентів якого дорівнює його змісту (Гузак, 2014: 72-76);

- один із компонентів мовної свідомості соціуму, що є одиницею усвідомлення загальнолюдських життєвих цінностей через мову за допомогою культурної пам'яті;

- це фундамент колективного дискурсу, умова ідеологічного взаєморозуміння і критерій соціальної ідентифікації, це одиниця осмислення людських цінностей через призму мови за допомогою культурної пам'яті; це відомий твір, актуалізований в інших текстах, звернення до якого скероване лінгвокогнітивними механізмами інтертекстуальності (Костомаров, 1996: 297-302).

Наведені дефініції свідчать, що визначення поняття прецедентного тексту відбувається у площинах категорій ціннісності, знаності, культурної значущості й подекуди інтертекстуальності.

Крім того, усі наведені визначення, відштовхуючись від класичного розуміння поняття тексту, вписують поняття «прецедентний текст» у вербальний вимір, обмежуючись тільки лінгвальною семіотичною системою.

Дещо по-іншому трактує прецедентний текст В. Красних. Дослідниця розуміє його як вербальний прецедентний феномен, що зберігається в когнітивній базі у вигляді інваріанта сприйняття. Згідно з їі тлумаченням, яке значною мірою грунтується на постмодерному трактуванні усієї дійсності як безперервного тексту, прецедентним текстом може бути й музичний твір, і твори живопису, й танець тощо - тобто твори інших семіотичних систем, що, проте, стали знаковими для певної спільноти. Якщо дотримуватися такого підходу, то прецедентним текстом не обов'язково має бути власне текст - ним можна вважати й окреме прислів'я або афоризм, які стали засобом вираження важливих рис світобачення та світорозуміння спільноти. Більше того, вони підходять до поняття креолізованого тексту. Це поняття стало важливою віхою у розробленні теорії інтертекстуальності, інтерсеміотичності та прецедентності, оскільки розширило погляд на природу того, що можна вважати прецедентним текстом. Для О. Анісімова креолізований текст - це особливий лінгвовізуальний феномен, у якому вербальна i невербальна частини формують єдине візуальне, структурне, смислове й функціональне ціле, чим досягається його комплексний прагматичний вплив на адресата (Анисимова 2003: 56).

У контексті дослідження Біблії поняття креолізованого тексту є вагомим з огляду на важливість релігійної візуальної символіки, зокрема хреста. Особливо відчутною роль візуального компонента була на ранніх етапах християнства, коли зовнішнє оформлення канонічної книги було частиною біблійного дискурсу, виражаючи пишною оздобою повагу й пієтет до вміщеного у книзі тексту. Зовнішне оформлення такої книги не могло залишати байдужим читача, а отже, ставало частиною того візуально-текстового комплексу, який і справляв вплив на свідомість.

Тож поступово уведений Ю. Карауловим термін, здобувши популярність у наукових колах, став основною для творення цілої низки інших термінологічних одиниць у працях В. Красних, Д. Гудкова, О. Фоміна, О. Березовича, Т. Смірнової, А. Проскуріної, Л. Балашової та ін. Серед таких термінологічних нововведень - терміносполуки «прецедентне ім'я», «прецедентна ситуація», «прецедентний жанр», «прецедентний світ», «прецедентний образ» тощо.

У контексті дослідження прецедентності Біблії докладнішої інтерпретації потребує термінологічна одиниця «прецедентний феномен», яка має ширший зміст, ніж прецедентний текст, і подекуди навіть витлумачена як родове щодо нього поняття. Ю. Прохоров пропонує підхід, у межах якого прецедентний феномен потрактований як гіперонім щодо понять «прецедентний текст», «прецедентна ситуація», «прецедентне висловлювання» та «прецедентне ім'я». Під прецедентною ситуацією учений пропонує розуміти «еталонну» ситуацію, з якою пов'язані певні конотації. Наприклад, 
такими $€$ новозавітні біблійні ситуації зради Ісуса Христа, молитви Христа в Саду Гетсиманському, зречення Петра, перетворення води на вино тощо.

Прецедентне ім'я - ім'я, пов'язане з певним текстом, і тому широко відоме у спільноті або ж ім'я, пов’язане $з$ певною ситуацією (Гудков, 2003: 151).

Такі імена набувають ціннісного значення i починають функціонувати як загальновідомі знаки й поза текстом, із якого з'явилися. Такими $€$ біблійні імена Адама як першого чоловіка, Сви як першої жінки, Каїна як братовбивці, Ісуса Христа як месії й Сина Божого, Іуди як зрадника, Матвія, Марка, Луки та Івана як євангелістів тощо.

На думку Т. Воробйової, під прецедентними феноменами варто розуміти когнітивні структури, які виникають на основі пізнавальної діяльності носіїв мови, зокрема як наслідок перегляду кінофільмів, читання однакових книг, прослуховування новин та обговорення суспільно-політичних подій у процесі соціологізації особистості [4, с. 124].

Отже, прецедентний текст $\mathrm{i}$ прецедентний феномен розглядаються переважно у двох різних вимірах - вербальному та когнітивному, перебуваючи у щонайтісніших зв'язках. Важливим у цьому контексті видається твердження О. Селіванової про прецедентний текст як простір реалізації вербальної прецедентного феномену (Селіванова, 2006: 591), яке заперечує положення Ю. Прохорова про те, що ці поняття перебувають у родо-видових зв'язках, оскільки відносить їх до явищ дещо різної природи. Це виразно засвідчують рівні прецедентності, які виділяє науковець. Серед них такі:

1) референційний, на якому прецедентність представлена ситуацією або сукупністю ситуацій, реальних чи ірреальних;

2) когнітивний, на якому прецедентність існує як концептуальна структура представлення ситуації (пропозиція, фрейм, ментальна модель);

3) вербальний - рівень, де прецедентність існує як прецедентне ім'я, прецедентна сполука, прецедентне висловлення, прецедентний текст чи його фрагмент.

Отже, вербальні засоби є інструментами актуалізації прецедентного феномену. Співвідношення вимірів когнітивного й вербального у явищі прецедентності В. Красних розглядає на прикладі прецедентного тексту і прецедентної ситуації. Дослідниця стверджує, що вони зберігаються у когнітивній базі у вигляді «інваріантів сприйняття» і можуть бути актуалізовані за допомогою вербальних засобів через реалізацію усього інваріанта сприйняття або через якусь деталь, атрибут чи символ прецедентного феномену. Власне, аби певний текст набув статусу прецедентного, він має спочатку пройти «когнітивний відбір» через «алгоритм сприйняття, який існує в певній національно-лінгво-культурній спільноті». Отримавши статус прецедентного феномена, вони стають «еталоном» тексту і значною мірою визначають алгоритм сприйняття тексту, котрий містить сигнал, що відсилає до текстів прецедентних. Торкаючись питання про звернення до текстів, які набули статусу прецедентних, К. Гудков підкреслює: прецедентні феномени актуалізуються в мовленні, прецедентні висловлення та прецедентні імена виступають як вербальні феномени, а прецедентні тексти та прецедентні ситуації - як такі, що можуть бути лінгвалізовані. Однак лінгвалізуються останні не повністю, а тільки через свої символи або сигнали, якими є прецедентні висловлювання та прецедентні імена, Отже, можна стверджувати, що дослідник виносить у когнітивний вимір не тільки поняття прецедентного феномену, а й поняття прецедентного тексту, який, як він стверджує, також перестає бути явищем лінгвальним і переноситься у свідомість мовця як інваріант сприйняття (Гудков, 2003: 109).

У своїй теорії прецедентного тексту Ю. Караулов одразу визначив поєднання у тексті емоційної та пізнавальної значущості, тобто здатність збуджувати інтелектуальні процеси й викликати емоційні реакції як основу для набуття ним статусу прецедентності. У теорії прецедентності ці два виміри, пізнавальний і емотивний, нерозривно пов'язані. «Це зумовлено тим, що когніція й емоція взаємозумовлені, тому що когніція викликає емоцію, оскільки вона емоціогенна, а емоції впливають на когніцію, тому що вони втручаються в усі рівні когнітивних процесів. Вони тісно пов'язані між собою у структурі особистості: когнітивні процеси супроводжуються емоціями, емоції когнітивно осмислюються〉 (Караулов, 2007: 89) Тож самої повторюваності звернення до тексту або його пізнавальності замало - він має набути й емоційно-ціннісного значення для людини.

Намагаючись з'ясувати, які ж виміри має явище прецедентності, Ю. Прохоров виділяє 4 рівні:

1) автопрецедентності (рівень мовної особистості як індивіда, визначається рівнем іiі індивідуальних знань і досвіду, пам'яттю тощо);

2) соціумно-прецедентний (ідеться про індивіда як представника певної соціальної групи члена родини, певної релігійної спільноти, представника певної професії тощо);

3) національно-прецедентний (рівень особистості як представника певної національності, котра має власний набір традицій, свої культурні символи тощо); 
4) універсально-прецедентний (рівень людини якпредставникалюдствазагаломізйогоуніверсальними цінностями та моральними настановами).

На відміну від Ю. Прохорова, В. Красних обмежується триступеневою класифікацією, не виділяючи індивідуальний рівень. Такий підхід видається виправданим, оскільки адекватне розуміння прецедентного сигналу в тексті, який має відсилку на прецедентний феномен, передбачає знайомство з останнім певної кількості осіб. Г. Слишкін, з огляду на кількість носіїв прецедентних текстів, зауважує, що є тексти, які $є$ прецедентними для вузького кола людей (малих соціальних груп) або для широкого.

Отже, саме поняття прецедентності та прецедентного тексту $є$ історично плинним і залежить від багатьох чинників. «Знання прецедентних феноменів говорить про належність реципієнта до певної епохи, ії культури, незнання ж їх свідчить про відторгнення від цієї культури, що говорить про його відстороненість від цієї культури або неповну “зануреність” у неї». Дослідження прецедентності у діахронії засвідчує, що спектр прецедентних феноменів у кожного покоління буде відмінним від попереднього. Знання їх є показником певної епохи та культури.
Прецедентні феномени можуть мати як національно-специфічний чи історично зумовлений, так і універсальний статус. Біблія є яскравим тому прикладом. Святе Письмо - прецедентний текст насамперед християнського релігійного дискурсу. У межах інших дискурсів воно може бути або визнаним авторитетним джерелом, або допускатися, або ж не визнаватися взагалі. Так, за радянської влади біблійні прецедентні сигнали були недопустимими. Однак на прецедентний феномен Біблію перетворює те, що до неї звертаються не тільки в межах художньої літератури, а й, наприклад, у політичному дискурсі, коли апелюють до мультиетнічної та мультирелігійної спільноти, викликаючи у них почуття єдності шляхом звернення до загальнолюдських цінностей та ідеалів (Костомаров, Бурвикова, 1996: 297-302).

Біблія входить в інші тексти на різних рівнях: цитації, імен, натяків і лексико-фразеологічних вкраплень або біблеїзмів, які становлять потужний прошарок у мовах християнських народів. Тож перспективним напрямом подальших досліджень $є$ 3'ясування характерних рис вживання біблеїзмів у різних функціонально-семантичних типах дискурсу, зокрема публіцистичному.

\section{СПИСОК ВИКОРИСТАНИХ ДЖЕРЕЛ}

1. Анисимова Е. Е. Лингвистика текста и межкультурная коммуникация (на материале креолизованных текстов) : учебное пособие. Москва : Издательский центр «Академия», 2003. 128 с.

2. Воробйова Т. В. Семантика прецедентних імен: національно-культурний компонент. Мова $i$ культура. 2003. Вип. 6. С. 119-127.

3. Гудков Д. Б. Теория и практика межкультурной коммуникации. Москва : ИТДГК «Гнозис», 2003. 288 с.

4. Гузак А. Біблія як прецедентний феномен та іiі роль у формуванні позитивного іміджу сучасного політичного лідера (на матеріалі промов американських президентів). Науковий вісник Міжнародного гуманітарного університету. Серія : Філологія. 2014. Вип. 8 (1). С. 72-76.

5. Караулов Ю. Н. Русский язык и языковая личность. Москва : Издательство ЛКИ, 2007. 264 с.

6. Костомаров В. Г., Бурвикова Н. Д. Прецедентный текст как редуцированный дискурс. Язык как творчество. Москва, 1996. С. 297-302.

7. Лялюк Я. Діахронічне дослідження лексики біблійних текстів в сучасній англійській мові. URL: http://eprints.zu.edu.ua/21309/1/\%D0\%9B\%D1\%8F\%D0\%BB\%D1\%8E\%D0\%BA.pdf (дата звернення: 17.03.2020).

8. Меркотан Л. Й. Прецедентний текст і способи його актуалізації в дискурсі української прози початку XXI століття. Наукові пращі Кам'янещь-Подільського національного університету імені Івана Огієнка. Філологічні науки. 2014. Вип. 37. С. 179-183.

9. Селіванова О. Сучасна лінгвістика: термінологічна енциклопедія. Полтава : Довкілля. Київ, 2006. 716 с.

10. Форманова С. Феномен прецедентності в романі Марії Матіос «Містер і місіс Ю-ко в країні укрів». URL: http://linguistics.kspu.edu/webfm_send/1238 (дата звернення: 17.03.2020).

\section{REFERENCES}

1. Anisimova E. E. Lingvistikateksta i mezhkul'turnaja kommunikacija (na materiale kreolizovannyh tekstov) : ucheb. posobie [Linguistics and text and intercultural communication (based on creolized texts)]. Moscow : Izdatel'skij centr "Akademija", 2003. 128 p. [in Russian]

2. Vorobiova T. V. Semantyka pretsedentnykh imen: natsionalno-kulturnyi komponent [Semantics of precedent names: national-cultural component]. Mova i kultura - Language and culture. 2003. Vol. 6, pp. 119-127. [in Ukrainian]

3. Gudkov D. B. Teorija i praktika mezhkul'turnoj kommunikacii. [Theory and practice of intercultural communication]. Moscow : ITDGK “Gnozis", 2003. 288 p. [in Russian]

4. Huzak A. Bibliia yak pretsedentnyi fenomen ta yii rol u formuvanni pozytyvnoho imidzhu suchasnoho politychnoho lidera (na materiali promov amerykanskykh prezydentiv) [The Bible as a precedent phenomenon and its role in shaping the 
positive image of the modern political leader (based on the speeches of American presidents)]. Naukovyi visnyk Mizhnarodnoho humanitarnoho universytetu. Seriia : Filolohiia - Scientific Bulletin of the International Humanities University. Series: Philology - Scientific Bulletin of the International Humanities University. Series: Philology. 2014, Vol. 8 (1), pp. $72-76$. [in Ukrainian]

5. Karaulov Ju. N. Russkij jazyk i jazykovaja lichnost [Russian language and linguistic personality]. Moscow : Izdatel'stvo LKI, 2007. 264 p. [in Russian]

6. Kostomarov V. G., Burvikova N. D. Precedentnyj tekst kak reducirovannyj diskurs [The precedent text as a reduced discourse]. Jazyk kak tvorchestvo - Language as creativity. Moscow, 1996, pp. 297-302. [in Russian]

7. Lialiuk Ya. Diakhronichne doslidzhennia leksyky bibliinykh tekstiv v suchasnii anhliiskii movi [Diachronic study of the vocabulary of biblical texts in modern English]. URL: http://eprints.zu.edu.ua/21309/1/\%D0\%9B\%D1\%8F\%D0\%BB\%D1\%8E\%D0\%BA.pdf (data zvernennia: 17.03.2020) [in Ukrainian]

8. Merkotan L. I. Pretsedentnyi tekst i sposoby yoho aktualizatsii v dyskursi ukrainskoi prozy pochatku KhKhI stolittia [Precedent text and ways of its actualization in the discourse of Ukrainian prose of the beginning of the XXI century]. Naukovi pratsi Kamianets-Podilskoho natsionalnoho universytetu imeni Ivana Ohiienka. Filolohichni nauky - Scientific works of Kamyanets-Podilsky National University named after Ivan Ogienko. Philological sciences. Kamianets-Podilskyi, 2014. Vol. 37, pp. 179-183. [in Ukrainian]

9. Selivanova O. Suchasna linhvistyka: terminolohichna entsyklopediia [Modern linguistics: terminological encyclopedia]. Poltava : Dovkillia. Kyiv, 2006. 716 p. [in Ukrainian]

10. Formanova S. Fenomen pretsedentnosti v romani Marii Matios "Mister i misis Yu-ko v kraini ukriv" [The phenomenon of precedent in Maria Mathios's novel "Mr. and Mrs. Yu-ko in the land of Ukrainians".]. URL: http://linguistics.kspu. edu/webfm_send/1238 (data zvernennia: 17.03.2020 [in Ukrainian]. 